\title{
Kontekstowość ocen sprawności organizacji
}

\author{
Dr hab. Witold Kowal, prof. UEW \\ Uniwersytet Ekonomiczny we Wrocławiu \\ Wydział Zarządzania, Katedra Zarządzania Marketingowego
}

\section{Wprowadzenie}

Współcześnie w badaniach naukowych (zwłaszcza tych związanych z naukami społecznymi) coraz częściej wyróżnia się podejście kontekstowe jako metodę wyjaśnień naukowych. Tego rodzaju podejście jest wykorzystywane najczęściej w badaniach z zakresu psychologii, lingwistyki, a także sztucznej inteligencji. Jego użyteczność jako podejścia badawczego została dostrzeżona także w naukach o zarządzaniu, choć nastąpiło to niedawno1. Godne odnotowania jest jednak to, iż tego rodzaju podejście badawcze charakterystyczne jest dla nauk związanych z nowymi technologiami (np. sztuczną inteligencją). Wydaje się to stanowić ważną przesłankę do uwzględnienia tego podejścia w badaniach związanych z naukami o zarządzaniu.

Celem opracowania jest dokonanie analizy dotychczasowego dorobku teoretycznego związanego z interpretacją sprawności organizacji, z wykorzystaniem podejścia kontekstowego jako metody wyjaśnień naukowych. Uzasadnieniem dla takiego podejścia badawczego może być to, iż dotychczasowy dorobek teoretyczny związany z ocenami organizacji charakteryzuje się dość dużą niejednorodnością. Mimo trwających od lat i dość licznych interpretacji takich kategorii jak skuteczność czy efektywność interpretacje istoty ocen organizacji są dość zróżnicowane. Być może inne podejście badawcze umożliwi sformułowanie lepszej płaszczyzny do porównań koncepcji teoretycznych formułowanych wokół takich kategorii jak sprawność, skuteczność czy też efektywność organizacji.

W naukach o zarządzaniu problem oceny organizacji stanowi przedmiot studiów o zróżnicowanym natężeniu. Oceniając go z dzisiejszej perspektywy, wydaje się, iż jest on dość ustabilizowany. Już dawno zostały wskazane kluczowe kategorie związane z tymi ocenami. Gorzej jest z interpretacją istoty tych ocen, czego wyrazem są nie tyle liczne publikacje, ile bardzo zróżnicowane definicje takich kategorii

1 Patrz: M. Porter, N. Siggelkov, Contextuality within Activity Systems and Substainability of Competitive Advantage, „Academy of Management Perspectives” 2008, vol. 22, no. 2, s. 34-56. 
jak skuteczność czy efektywność ${ }^{2}$. W naszej tradycji badawczej problem ocen organizacji kojarzony jest przede wszystkim z kategorią sprawności oraz jej walorami. Zainicjowany przez Kotarbińskiego ${ }^{3}$ kierunek interpretacji tych kategorii stopniowo ewoluował i z obecnej perspektywy sprawność organizacji kojarzona jest przede wszystkim z kategoriami skuteczności i efektywności. W anglojęzycznym dorobku teoretycznym co prawda trudno znaleźć ekwiwalentny odpowiednik dla kategorii sprawności, ale problematyka ocen organizacji jest równie często podejmowana i kojarzona $\mathrm{z}$ kategoriami effectiveness i efficiency. W odniesieniu do ocen organizacji kategorie te interpretowane są jako dwa alternatywne wymiary tych ocen lub osobno. W tym ostatnim przypadku najliczniej reprezentowany jest dorobek badawczy związany z organizational effectiveness. W ramach dokonanych poniżej analiz problem ocen sprawności organizacji związany będzie ze wskazanymi kategoriami, tj. skutecznością (effectiveness) i efektywnością (efficiency).

\section{Podejście kontekstowe jako metoda wyjaśnień naukowych}

Z teoretycznego punktu widzenia kontekst ujawnia się w procesach decyzyjnych i zachowaniach społecznych. Cechą wyróżniającą jest to, iż odzwierciedla on problem interakcji, jaka zachodzi między zdarzeniami. Tego rodzaju interakcję można wykorzystać w badaniach naukowych. W licznych przykładach interpretacji kontekstu jako kategorii naukowej zwraca się uwagę na warunki towarzyszące wydarzeniu, zorientowaną aktywność ${ }^{4}$, zestaw cech danej sytuacji, element transformacji danych $\mathrm{w}$ informacje $\mathrm{e}^{5}$ lub interakcje pomiędzy różnymi działaniami ${ }^{6}$. Jednocześnie zwraca się uwagą na to, iż modele kontekstowe są epizodyczne, osobiste i subiektywne?

2 Patrz: W. Kowal, Sprawność organizacji. Emocjonalne, behawioralne i finansowe efekty dziatań marketingowych w ocenie skuteczności i efektywności przedsiębiorstwa, Wydawnictwo Uniwersytetu Ekonomicznego we Wrocławiu, Wrocław 2015.

3 T. Kotarbiński, Traktat o dobrej robocie, Ossolineum, Wrocław - Warszawa - Kraków - Gdańsk - Łódź 1982.

4 G. Tiberghien, Context and cognition: Introduction, „Cahiers de Psychologie Cognitive” 1986, vol. 6, nr 2, s. 107.

5 J.-Ch. Pomerol, P. Brézillon, About some relationships between Knowledge and Context, [w:] V. Akman i wsp. (red.), Modeling and Using Context, CONTEXT 2001, seria „Lecture Note in Computer Science”, vol. 2116, Springer, Berlin - Heidelberg 2001, s. 6-7.

6 M. Porter, N. Siggelkov, Contextuality within Activity Systems..., s. 34.

7 T.A. van Dijk, Discourse, Ideology and Context, „Folia Linguistica” 2001, vol. 35, no. 1-2, s. 11-40. 
Zasadniczym problemem w interpretacji kontekstu w procesie decyzyjnym lub zachowaniach podmiotów myślących jest punkt odniesienia, czego wyrazem jest relacja między takimi kategoriami jak wiedza i postawa. Tu daje się wyodrębnić dwie interpretacje. W ramach pierwszej z nich postrzega się kontekst jako zmianę postawy w wyjaśnieniu zjawisk, na przykład psychologicznych ${ }^{8}$, jako ogniwo pomiędzy postawami a zachowaniami, powiązane ze strukturami i strategiami rozważanych zjawisk, na przykład dyskursem. W ramach drugiego podejścia postrzega się kontekst jako ogniwo ${ }^{9}$ pomiędzy wiedzą a decyzjami i zachowaniami, jako element transformacji informacji w wiedzęi10.

Te pierwsze sytuacje są dość oczywiste. Mamy do czynienia z jakimiś modelem mentalnym (reprezentacjami mentalnymi). Zdarzenia komunikacyjne, decyzje czy też zachowania podmiotów myślących nie są bezpośrednim następstwem tych reprezentacji mentalnych, ale efektem interakcji kontekstowej, która może je modyfikować lub warunkować. Model kontekstowy jest zatem interfejsem między reprezentacją mentalną a zdarzeniem ${ }^{11}$. Kategoriami efektów kontekstowych mogą być percepcja lub sposób rozumowania podmiotów myślących ${ }^{12}$. Zależy to od celu tego podmiotu i typu kontekstu. Dopuszczamy zatem zmienność zachowań na skutek zmian w percepcji lub sposobie rozumowania.

W ramach drugiej interpretacji (kontekst jako ogniwo między wiedzą a zachowaniami) kontekst nie jest kojarzony z postawami, a bezpośrednio z wiedzą. Identyfikuje się zatem wiedzę kontekstową oraz sam kontekst, tzw. kontekst proceduralny ${ }^{13}$. Wiedza kontekstowa jest ustalona, ma charakter zewnętrzny i dotyczy kulis zdarzenia, podstawowych cech sytuacji. Kontekst proceduralny jest częścią kontekstualnej wiedzy skoncentrowanej na zadaniu, ustrukturyzowanej adekwatnie do tego zadania, związanej z aktywnością, umożliwiającą przewidywanie wyników działania.

Porter i Siggelkov dokonali interpretacji kontekstu w odniesieniu do działań firmy i wyodrębnili konteksty działań oraz interakcję kontekstową ${ }^{14}$. W ich interpretacji wartości indywidualnych działań firmy są pod wpływem innych jej działań,

8 G. Tiberghien, Context and cognition..., s. 105.

9 T.A. van Dijk, Cognitive Context Models in Discourse, [w:] M.I. Stamenov(red.), Language Structure, Discourse and Access to Consciousness, John Benjamins Publishing Company, Amsterdam - Philadelphia 1997, s. 189-226.

10 J.-Ch. Pomerol, P. Brézillon, About some relationship..., s. 7.

11 T.A. van Dijk, Cognitive Context Models..., s. 189-226.

12 G. Tiberghien, Context and cognition..., s. 111.

13 J.-Ch. Pomerol, P. Brézillon, About some relationship..., s. 7.

14 M. Porter, N. Siggelkov, Contextuality within Activity Systems..., s. 35. 
które są zależne, komplementarne. Przedmiotem zainteresowania podejścia kontekstowego są zatem interakcje pomiędzy różnymi aktywnościami firmy.

Z powyższych interpretacji można wyciągnąć wniosek, iż kontekstowość kojarzona jest przede wszystkim z interakcyjnością pomiędzy działaniami lub między wiedzą a działaniami. Interakcyjność może być oparta na wiedzy kontekstowej, która jest reprezentowana przez wiele badań skoncentrowanych na pomiarach zmienności decyzji czy też współzależnościach zachowań.

\section{Kontekstowość na poziomie interpretacji istoty ocen sprawności organizacji}

W literaturze przedmiotu daje się zidentyfikować wiele przykładów ocen związanych z zarządzaniem lub bezpośrednio z organizacjami. W tym nurcie publikacyjnym dominują próby formułowania uniwersalnych systemów ocen organizacji, które obejmują mniej lub bardziej zróżnicowany zestaw kryteriów. Poza nielicznymi wyjątkami, na przykład interpretacjami polskiej szkoły prakseologii, Jacksona $^{15}$, Cabały ${ }^{16}$, Shawa ${ }^{17}$, w ramach których identyfikuje się większą liczbę kryteriów oceny organizacji, najczęściej formułowane są dwukryterialne systemy oceny organizacji. Są one oparte na kryteriach skuteczności i efektywności. Studia publikacji z zakresu interpretacji tych kategorii w odniesieniu do problemu ocen organizacji pozwalają zauważyć, iż aspekty kontekstowe pojawiają się stosunkowo rzadko. Na podstawie dokonanych analiz można wskazać trzy poziomy, w których kontekstowość tej wiedzy była wskazywana, tj.:

- poziom interpretacji istoty ocen sprawności organizacji;

- poziom interpretacji pojedynczej kategorii;

- poziom miar, kryteriów ocen organizacji.

Przedstawione poniżej przykłady interpretacji uporządkowane będą według wyżej wymienionych poziomów problemów interpretacji sprawności organizacji.

Przeglądając ogół dorobku teoretycznego, można zauważyć dwa podejścia w interpretacji ocen organizacji. Podstawę do interpretacji sprawności organizacji mogą stanowić jej wyniki lub zachowania jednostek i podmiotów. Stanowi to przesłankę do identyfikacji dwóch podejść do interpretacji istoty ocen

15 J. Jackson, Reporting on management effectiveness, „CMA Magazine” 1991, vol. 65, no. 9, s. 16-19.

16 P. Cabała, Wprowadzenie do prakseologii. Przegląd zasad skutecznego działania, Wydawnictwo Akademii Ekonomicznej w Krakowie, Kraków 2007.

17 E.H. Shaw, A general theory of systems performance criteria, „International Journal of General Systems" 2009, vol. 38, no. 8, s. 851-869. 
organizacji, tj. podejścia wynikowego i behawioralnego ${ }^{18}$. Przykładów interpretacji opartych na podejściu wynikowym jest najwięcej i pojawiły się one najwcześniej. Tego rodzaju podejścia daje się zauważyć między innymi w interpretacjach Koontza, O’Donnella i Weihricha ${ }^{19}$, Simonsa ${ }^{20}$ czy Davisa i Petta ${ }^{21}$. Podejście behawioralne jest przede wszystkim związane $\mathrm{z}$ interpretacją Druckera ${ }^{22}$.

Jak sama nazwa wskazuje, podejście wynikowe przyjmuje jako podstawę do ocen organizacji jej wyniki, a dokładnie wielopoziomowy układ celów organizacji oraz wyników tych działań (m.in. kosztów). Skuteczność jest relacją między wynikami i celami organizacji. Z kolei efektywność jest relacją między wynikami a kosztami lub wejściem i wyjściem. Łączna interpretacja obu tych postaci sprawności pozwala zauważyć, iż przejawem funkcjonowania organizacji są jej wyniki. Dla organizacji, która chce kreować swoje wyniki, istnieją dwa punkty odniesienia: cele i koszty. Z jednej strony organizacja wyznacza cele, które stanowią podstawę jej istnienia i regulują działania, $\mathrm{z}$ drugiej strony skazana jest na ponoszenie kosztów związanych z jej funkcjonowaniem.

Korzeni podejścia behawioralnego należy poszukiwać w interpretacji skuteczności i efektywności dokonanej przez Druckera. Zdefiniował on skuteczność jako „robić właściwe rzeczy”, a efektywność jako „robić rzeczy właściwie”23. Istotą podejścia behawioralnego jest interpretacja zachowań organizacji (działań i procesów) oraz wszystkich tych elementów, które je determinują. W tego rodzaju ocenach dominuje problem wyborów dokonywanych w organizacji, które dotyczą jej celów oraz działań i procesów związanych z tymi celami.

Użyteczność tego rodzaju podziału ocen organizacji można uzasadnić właśnie kontekstowością. Co prawda komplikuje to wiedzę na temat ocen organizacji, sprawia, iż teoria ocen organizacji staje się złożona, ale podejście kontekstowe eksponuje specyfikę ocen sprawności z punktu widzenia czasu. Podejście wynikowe daje podstawę do sformułowania oceny ex-post, która opiera się na rzeczywistych wynikach organizacji. Podejście behawioralne sprzyja ocenom ex-ante. W ramach podejścia wynikowego dokonuje się oceny wartości liczbowych, co pozwala na sformułowanie bardziej jednoznacznych i ostatecznych ocen sprawności organizacji. Oba podejścia można jednak traktować jako uzupełniające się systemy ocen, przy założeniu istotności czynnika czasu jako momentu oceny.

18 W. Kowal, Sprawność organizacji..., s. 57-63.

19 H. Koontz, C. O'Donnell, H. Weihrich, Management.

20 R. Simons, Performance Measurement...

21 P.S. Davis, T.L. Pett, Measuring Organizational Efficiency..., s. 87-97.

22 P. Drucker, Management...

23 Tamże, s. 44. 


\section{Kontekstowość na poziomie interpretacji pojedynczej kategorii}

Inne przykłady wykorzystania podejścia kontekstowego w wyjaśnieniach istoty ocen sprawności organizacji można zaobserwować w przypadku studiów nad pojedynczą kategorią (walorem) sprawności, tj. organizational effectiveness. W polskiej literaturze przedmiotu kategoria ta jest określana jako efektywność organizacji. Może nie jest to poprawne lingwistycznie odniesienie dla tej kategorii (właściwsza byłaby skuteczność organizacji), ale taka nazwa kategorii upowszechniła się w latach siedemdziesiątych i osiemdziesiątych ubiegłego wieku za sprawą interpretacji dokonanych między innymi przez Kownackiego ${ }^{24}$ i Kosteckiego ${ }^{25}$. Interpretacja istoty organizational effectiveness była i jest przedmiotem licznych publikacji. Ich efektem jest upowszechnienie się wielu koncepcji teoretycznych, wyrażonych licznymi modelami. W literaturze przedmiotu daje się wyodrębnić następujące modele organizational effectiveness ${ }^{26}$ : model racjonalnego celu, model celowy, model racjonalny, model systemu racjonalnego, model zasobów systemowych, model procesu kierowania (zarządzania), model rozwoju organizacyjnego, model negocjacyjny, model funkcjonalny, model procesów wewnętrznych, model strategicznej klienteli, model konkurencyjnej wartości, model oparty na błędach, model nieskuteczności, model systemu naturalnego, model systemu otwartego, model satysfakcji z uczestnictwa, model możliwości strukturalnych. Większość z nich ma charakter uniwersalny. Cechą charakterystyczną dla tych interpretacji stało się to, iż te początkowe kojarzyły ocenę organizacji z pojedynczymi kryteriami. W następstwie rozwoju studiów rozwijano zakres kryteriów kojarzonych z oceną organizacji, ale te nowe modele traktowano także jako uniwersalne. Nawet wyłonienie się refleksji o wielokryterialności ocen organizacji nie oznaczało zarzucenia dążenia do uniwersalności kryteriów sprawności. Podejście kontekstowe daje się zauważyć w nielicznych interpretacjach, między innymi Quinna i Cameron ${ }^{27}$ oraz Gaertnera i Ramnarayana ${ }^{28}$.

Quinn i Cameron zaproponowali tzw. model konkurencyjnej wartości (określany także jako podejście). W swojej koncepcji podzielili podejścia do oceny

24 S. Kownacki, Miary efektywności organizacyjnej, „Problemy Organizacji” 1976, nr 2, s. 51-67.

25 M.J. Kostecki, Socjologiczna koncepcja efektywności organizacyjnej, „Problemy Organizacji” 1980, nr 1, s. 53-73.

26 W. Kowal, Sprawność organizacji..., s. 40.

27 R.E. Quinn, K. Cameron, Organizational life cycles and shirting criteria of effectiveness: Some preliminary evidence, „Management Science” 1983, vol. 29, no. 1, s. 33-51.

28 G.H. Gaertner, S. Ramnarayan, Organizational effectiveness: An alternative perspective, „Academy of Management Review" 1983, vol. 8, no. 1, s. 97-107. 
organizacji według trzech pierwotnych wymiarów ${ }^{29}$ : koncentracja wewnętrzna a koncentracja zewnętrzna (np. indywidualna satysfakcja a osiąganie celu organizacji), założenie elastyczności a koncentracja na kontroli (np. innowacja i adaptacja a przewidywanie i stabilizacja) oraz koncentracja na celu a koncentracja na środkach. Wymiary te przedstawiają sprzeczne wartości, które ujawniają się przy ocenach organizacji. To założenie początkowe pozwala im na wyodrębnienie czterech modeli organizational effectiveness, tj. racjonalnego celu, procesu wewnętrznego, systemu otwartego i relacji ludzkich ${ }^{30}$. Każdy z zaproponowanych modeli zlokalizowany został w układzie współrzędnych opisanych konkurencyjnymi wartościami, którymi są cele i środki realizacji. Model racjonalnego celu za kryterium oceny skuteczności uznaje jej produktywność i wydajność, model procesu wewnętrznego za kryterium efektywności uznaje stabilność i kontrolę, a model systemu otwartego za kryterium efektywności uznaje zasoby i rozwój. Tak zarysowana interpretacja organizational effectiveness demonstruje ocenę sprawności organizacji jako problem kontekstowy. Warte podkreślenia jest to, iż autorzy skoncentrowali się na różnych mechanizmach wykorzystywanych w ocenie.

Inny przykład wykorzystania podejścia kontekstowego do interpretacji alternatywności ocen organizational effectiveness przedstawili Gaertner i Ramnarayan. Większość dorobku związanego z interpretacją organizational effectiveness traktują oni jako rozwiązania alternatywne, których wybór determinowany jest różnymi czynnikami. W swojej propozycji wprowadzają dwa wymiary (kryteria), tj. skoncentrowanie na definicji kategorii i intencje wykorzystania koncepcji ${ }^{31}$. Wiele definicji koncentruje się na pomiarze ostatecznych wyników, a inne na pomiarach procesów i struktur organizacyjnych. Natomiast intencje wykorzystania Gaertner i Ramnarayan opisują dążeniami do oceny konkretnych organizacji lub generalizowania. W efekcie sformułowali cztery podejścia ${ }^{32}$. Pierwsze podejście do ocen organizacji (tzw. ogólne miary wyjścia) oparte jest na rachunkowości, drugie (tzw. miary wyjścia specyficzne dla organizacji) na celach organizacji, trzecie (tzw. miary ogólne) na określeniu aspektów działań organizacyjnych (np. stylów zarządzania, podejmowania decyzji i struktur organizacyjnych), które poprawiają sprawność organizacji, a ostatnie (tzw. ogląd, punkt widzenia specyficzny dla organizacji) kładzie nacisk na oceny jakościowe procesu. W tych czterech podejściach do ocen effectiveness wykorzystane zostały podejścia skorelowane z interpretacją istoty sprawności organizacji, która odzwierciedlana jest w podejściu wynikowym

29 R.E. Quinn, K. Cameron, Organizational life cycles..., s. 41.

30 Tamże, s. 42.

31 G.H. Gaertner, S. Ramnarayan, Organizational effectiveness..., s. 97-98.

32 Tamże, s. 98-100. 
i behawioralnym. Zostały tu uwzględnione aspekty ilościowe ocen organizacji, a także aspekty jakościowe. $Z$ tego punktu widzenia jest to najszersza koncepcja kontekstowości ocen organizacji.

W odniesieniu do wskazanych powyżej koncepcji ocen należy jednak zwrócić uwagę, iż żaden z przytoczonych powyżej modeli nie został rozpowszechniony. W różnych publikacjach podsumowujących całość dorobku koncepcyjnego najczęściej opisuje się modele uniwersalne ${ }^{33}$. Współcześnie problem ocen organizacji ustąpił miejsca problematyce dokonań organizacji (performance), w której pomiar wyników (ich miary) stał się dominującym przedmiotem zainteresowania.

Jest jeszcze jeden problem związany z przedstawionymi powyżej modelami, tj. problem alternatywności wiedzy. Oba modele ocen organizacji są konkurencyjne względem siebie. Ich równoległe funkcjonowanie nie jest wskazane, gdyż sprzyja złożoności wiedzy naukowej, a także jej subiektywności. Konieczne jest dokonanie wartościowania tych modeli, chociażby po to, by zaoferować praktyce biznesowej jednoznaczne wyjaśnienia.

\section{Kontekstowość na poziomie miar, kryteria ocen sprawności organizacji}

Jeszcze innym przykładem kontekstowości w podejściu do ocen sprawności jest problem interpretacji kryteriów, miar i wyników wykorzystywanych do tych oceny. Prowadzi on nas jeszcze dalej - do kategorii performance. Związek między problemami oceny organizacji (organizational effectiveness) a performance był już wskazywany dość dawno ${ }^{34}$. Równie wcześnie został zauważony problem kontekstowości 35 .

W modelu klienteli strategicznej (lub klienteli wielorakiej) zaakcentowany został kontekstowych charakter ocen opartych na celach organizacji. Według Connolly'ego, Conlona i Deutscha ocena organizacji zawiera wiele różnych sformułowań poczynionych dla konkretnej organizacji, odzwierciedlających zestaw kryteriów różnych jednostek i grup, określonych jako klientela ${ }^{36}$. Dla nich organizacja to podmiot,

33 Patrz: J.-F. Henri, Performance measurement and organizational effectiveness: Bridging the gap, „Managerial Finance” 2004, vol. 30, no. 6, s. 93-123.

34 Między innymi W.R. Scott, Effectiveness of Organizational Effectiveness Studies, [w:] P.S. Goodman, J.M. Pennings (red.), New Perspectives on Organizational Effectiveness, Jossey-Bass, San Francisco 1977, s. 63-96; R.M. Kanter, D. Brinkerhoff, Organizational performance: Recent developments in measurement, „Annual Review of Sociology” 1981, no. 7, s. 321-349.

35 Patrz: T. Connolly, E.J. Conlon, S.J. Deutsch, Organizational effectiveness: A multiple-constituency approach, „Academy of Management Review” 1980, vol. 5, no 2, s. 211-217.

36 Tamże, s. 212. 
w którym ujawnia się rywalizacja różnych grup interesu. W efekcie ocena organizacji będzie dokonywana z perspektywy różnych oczekiwanych wyników tych grup. W tym ujęciu akcentuje się, iż organizacje są instrumentami wykorzystywanymi do realizacji celów różnorakiej klienteli.

Uzasadnienia dla zilustrowania tego problemu nie trzeba poszukiwać zbyt daleko. Wystarczy, że oprzemy się na tradycyjnym modelu celu organizacji jako kryterium oceny jej skuteczności, by zauważyć złożoność i brak jednoznaczności w interpretacji celu organizacji. Bazując na teoriach przedsiębiorstwa, można zauważyć zmienność ich celów, które można podzielić na ${ }^{37}$ :

- cele tradycyjne, związane z neoklasyczną teorią przedsiębiorstwa;

- cele menedżerskich teorii przedsiębiorstwa;

- cele związane z finansowymi teoriami przedsiębiorstwa.

Tego rodzaju obserwacja prowadzi nas do rozpatrywania całego spektrum możliwych celów organizacji - od klasycznego już zysku po wartości firmy. Na przykład Rappaport ${ }^{38}$ rozpatruje ten problem przez pryzmat czterech możliwych, a zarazem alternatywnych miar finansowych: zysku księgowego, stopy zwrotu $\mathrm{z}$ inwestycji (ROI), stopy zwrotu z kapitału własnego (ROE) oraz zysku na akcji, czyli wzrostu wartości rynkowej akcji przedsiębiorstwa ${ }^{39}$. W literaturze przedmiotu daje się zauważyć wiele interpretacji różnego rodzaju produktywności, które odnoszą się do miar finansowych jako celów organizacji. W tego rodzaju interpretacjach należy postrzegać kontekstowość ocen organizacji, gdyż wskazane powyżej cele finansowe organizacji mają swoje uwarunkowania historyczne i bardzo często są powiązane właśnie ze strategiczną lub wieloraką klientelą organizacji. Taką zmianę kryterium oceny (związaną ze strategiczną klientelą organizacji) można uzasadniać i na tej podstawie wskazać przesunięcie ocen organizacji.

W szerszym wymiarze problem kontekstowości miar oceny organizacji wiąże się z interpretacją dokonań przedsiębiorstwa (w literaturze anglojęzycznej dorobek ten odnosi się do kategorii business performance, firm performance, company performance lub corporate performance). W ramach licznych interpretacji kategorii dokonań przedsiębiorstwa oraz identyfikacji i klasyfikacji ich mierników pojawiło się wiele propozycji kwestionariuszy, macierzy czy też systemów dokonań ${ }^{40}$.

37 T. Gruszecki, Współczesne teorie przedsiębiorstwa, Wydawnictwo Naukowe PWN, Warszawa 2002, s. 156-187.

38 A. Rappaport, Wartość dla akcjonariuszy. Poradnik menedżera i inwestora, WIG-Press, Warszawa 1999.

39 Tamże, s. 15-35.

40 Patrz: M. Kotłowska, R. Kowalak, Kluczowe mierniki dokonań w zarzq̨dzaniu przedsiębiorstwem, Wydawnictwo Uniwersytetu Ekonomicznego we Wrocławiu, Wrocław 2016. 
Wskazany powyżej problem strategicznej klienteli i niejednoznaczności celów organizacji stanowi kolejny przykład alternatywności wiedzy i potrzeby jej selekcji.

\section{Podsumowanie}

Przedstawione powyżej analizy pozwalają zauważyć, iż w dorobku teoretycznym związanym z oceną sprawności organizacji istnieją przykłady badań, których efektem jest wiedza kontekstowa (na poziomie interpretacji kategorii lub kryteriów oceny sprawności organizacji), jak również sytuacje, w których takie podejście mogłoby być uzasadnione (np. przy interpretacji istoty ocen organizacji). Konsekwencją tego rodzaju podejścia badawczego jest jednak problem złożoności teorii oraz uniwersalności wiedzy. Przedstawione powyżej modele konkurencyjnej wartości czy też Gaertnera-Ramnarayana ilustrują efekty koncepcyjne takiego właśnie podejścia badawczego. Oba modele, same w sobie, są jednak konkurencyjne. Tego rodzaju efekt - wielość i alternatywnych teorii - stanowić może problem zarówno dla wyjaśnień naukowych, jak i dla praktyki biznesowej. Nie dyskryminuje to jednak podejścia kontekstowego jako metody wyjaśnień naukowych, ale wskazuje na problem weryfikacji sformułowanej w ten sposób wiedzy teoretycznej.

\section{Bibliografia}

Cabała P., Wprowadzenie do prakseologii. Przegląd zasad skutecznego działania, Wydawnictwo Akademii Ekonomicznej w Krakowie, Kraków 2007.

Connolly T., Conlon E.J., Deutsch S.J., Organizational effectiveness: A multiple-constituency approach, „Academy of Management Review” 1980, vol. 5, no 2, s. 211-217.

Davis P.S., Pett T.L., Measuring Organizational Efficiency and Effectiveness, „, Journal of Management Research" 2002, vol. 2, no. 2, s. 87-97.

Dijk T.A. van, Cognitive Context Models in Discourse, [w:] M.I. Stamenov (red.), Language Structure, Discourse and Access to Consciousness, John Benjamins Publishing Company, Amsterdam - Philadelphia 1997, s. 189-226.

Dijk T.A. van, Discourse, Ideology and Context, „Folia Linguistica” 2001, vol. 35 no. 1-2, s. 11-40. Drucker P., Management. Tasks, Responsibilities, Practices, Butterworth Heinemann, Oxford 1988. Gaertner G.H., Ramnarayan S., Organizational effectiveness: An alternative perspective, „Academy of Management Review" 1983, vol. 8, no. 1, s. 97-107.

Gruszecki T., Współczesne teorie przedsiębiorstwa, Wydawnictwo Naukowe PWN, Warszawa 2002. Henri J.-F., Performance measurement and organizational effectiveness: Bridging the gap, „Managerial Finance" 2004, vol. 30, no. 6, s. 93-123.

Jackson J., Reporting on management effectiveness, „CMA Magazine” 1991, vol. 65, no. 9, s. 16-19. Kanter R.M., Brinkerhoff D., Organizational performance: Recent developments in measurement, „Annual Review of Sociology” 1981, no. 7, s. 321-349.

Koontz H., O’Donnell C., Weihrich H., Management, McGraw-Hill, New York 1984. 
Kostecki M.J., Socjologiczna koncepcja efektywności organizacyjnej, „Problemy Organizacji” 1980, nr 1, s. 53-73.

Kotarbiński T., Traktat o dobrej robocie, Ossolineum, Wrocław - Warszawa - Kraków - Gdańsk - Łódź 1982.

Kotłowska M., Kowalak R., Kluczowe mierniki dokonań w zarzq̨dzaniu przedsiębiorstwem, Wydawnictwo Uniwersytetu Ekonomicznego we Wroctawiu, Wrocław 2016.

Kowal W., Sprawność organizacji. Emocjonalne, behawioralne i finansowe efekty dziatań marketingowych w ocenie skuteczności i efektywności przedsiębiorstwa, Wydawnictwo Uniwersytetu Ekonomicznego we Wrocławiu, Wroctaw 2015.

Kownacki S., Miary efektywności organizacyjnej, „Problemy Organizacji” 1976, nr 2, s. 51-67.

Pomerol J.-Ch., Brézillon P., About some relationships between Knowledge and Context, [w:] V. Akman, Bouquet P., Thomason R., Young R. (red.), Modeling and Using Context, CONTEXT 2001, seria „Lecture Note in Computer Science”, vol. 2116, Springer, Berlin - Heidelberg 2001, s. 461-464.

Porter M., Siggelkov N., Contextuality within Activity Systems and Substainability of Competitive Advantage, „Academy of Management Perspectives” 2008, vol. 22, no. 2, s. 34-56.

Quinn R.E., Cameron K., Organizational life cycles and shirting criteria of effectiveness: Some preliminary evidence, „Management Science” 1983, vol. 29, no. 1, s. 33-51.

Rappaport A., Wartość dla akcjonariuszy. Poradnik menedżera i inwestora, WIG-Press, Warszawa 1999.

Scott W.R., Effectiveness of Organizational Effectiveness Studies, [w:] P.S. Goodman, J.M. Pennings (red.), New Perspectives on Organizational Effectiveness, Jossey-Bass, San Francisco 1977, s. 63-96.

Shaw E.H., A general theory of systems performance criteria, „International Journal of General Systems" 2009, vol. 38, no. 8, s. 851-869.

Simons R., Performance Measurement and Control Systems for Implementing Strategy, Prentice-Hall, Upper Saddle River 2000.

Tiberghien G., Context and cognition: Introduction, „Cahiers de Psychologie Cognitive” 1986, vol. 6, no. 2, s. 105-119.

\section{Streszczenie}

Podejście kontekstowe jest metodą badawczą, która staje się coraz bardziej powszechna w naukach społecznych. Celem opracowania jest dokonanie analizy dotychczasowego dorobku teoretycznego związanego z interpretacją sprawności organizacji, z wykorzystaniem podejścia kontekstowego jako metody wyjaśnień naukowych. To podejście stwarza nowe możliwości badawcze, a z drugiej strony ujawnia problemy uniwersalności wiedzy naukowej. Dokonane analizy pozwalają zauważyć, iż w dorobku teoretycznym związanym z oceną sprawności organizacji daje się zauważyć przykłady wiedzy kontekstowej. Kontekstowe teorie stwarzają problem alternatywności wiedzy. Nie dyskryminuje to jednak kontekstowości jako metody wyjaśnień naukowych, ale wskazuje na problem weryfikacji sformułowanej w ten sposób wiedzy teoretycznej.

Słowa kluczowe: kontekstowość, sprawność organizacji, skuteczność, efektywność 
Contextality of assessing organizational effectiveness and efficiency

\section{Abstract}

The contextual approach is a research method that is becoming increasingly popular in social sciences. The aim of this paper is to analyze the theoretical achievements related to the interpretation of assessment of the organization using a contextual approach as a method of scientific explanation. This approach creates new research opportunities. On the other hand, it reveals the problems of universality of scientific knowledge. The analyzes show that theoretical achievements related to the assessment of the organization show examples of contextual knowledge. But contextual theories pose a problem of the alternativeity of knowledge. However, this does not discriminate contextuality as a method of scientific explanation, but points to the problem of verification of theoretical knowledge formulated in this way.

Keywords: contextuality, assessment of organization, effectiveness, efficiency 